\title{
Federalism and International Human Rights in the New Constitutional Order
}

Mark V. Tushnet

Georgetown University Law Center, tushnet@law.georgetown.edu

This paper can be downloaded free of charge from:

https://scholarship.law.georgetown.edu/facpub/250

47 Wayne L. Rev. 841-869 (2001)

This open-access article is brought to you by the Georgetown Law Library. Posted with permission of the author. Follow this and additional works at: https://scholarship.law.georgetown.edu/facpub

Part of the Constitutional Law Commons, and the Human Rights Law Commons 


\title{
GEORGETOWN LAW Faculty Publications
}

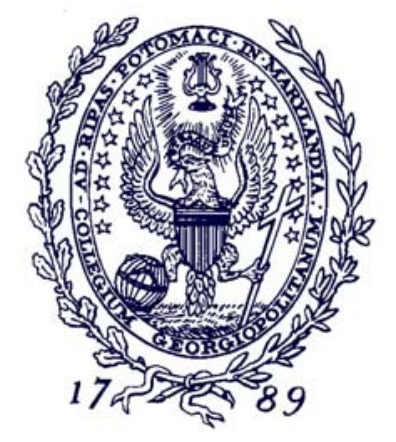

February 2010

\section{Federalism and International Human Rights in the New Constitutional Order}

47 Wayne L. Rev. 841-869 (2001)

\author{
Mark V. Tushnet \\ Professor of Law \\ Georgetown University Law Center \\ tushnet@law.georgetown.edu
}

This paper can be downloaded without charge from:

Scholarly Commons: http://scholarship.law.georgetown.edu/facpub/250/

Posted with permission of the author 


\title{
FEDERALISM AND INTERNATIONAL HUMAN RIGHTS IN THE NEW CONSTITUTIONAL ORDER
}

\author{
MARK TUSHNET ${ }^{\dagger}$ \\ Table of Contents
}

I. INTRODUCTION . . . . . . . . . . . . . . . . . . . . 841

II. FOREIGN AFFAIRS AND MODERN CONSTITUTIONAL

ORDERS ............................ 843

III. FEDERAIISM AND INTERNATIONAL HUMAN RIGHTS

LAW ........................... 847

IV. FEDERALISM, INTERNATIONAI HUMAN RIGHTS, AND

THE NEW CONSTTTUTIONAL ORDER . . . . . . . . . 852

A. A Framework for Evaluating the Need for Constitutional

Doctrine......................... 852

B. Federalism Limitations on the Power Over Foreign

Affairs ........................... 855

1. Subject-Matter Limitations . . . . . . . . . . 856

2. The Anti-Commandeering Principle ......... 863

V. CONCLUSION ........................ 869

\section{INTRODUCTION}

This Essay examines the contours of what I have elsewhere called the new constitutional order ${ }^{1}$ with respect to international human rights and federalism. The background is my suggestion that the U.S. political-constitutional system is on the verge of moving into a new constitutional regime, following the end of the New Deal-Great Society constitutional regime. ${ }^{2}$ The Supreme Court's innovations in the law of federalism in connection with Congress's exercise of its powers over domestic affairs has provoked

${ }^{\dagger}$ Carmack Waterhouse Professor of Constitutional Law, Georgetown University Law Center. B.A., 1967, Harvard University; M.A., 1971, Yale University, J.D., 1971, Yale University Law School. I would like to thank L. Michael Seidman, Peter Spiro, and Carlos Manuel Vázquez for their comments on a draft of this Essay, and Jacqueline Shapiro for her usual top-notch work as a research assistant.

1. See Mark Tushnet, Foreword: The New Constitutional Order and the Chastening of Constitutional Ambition, 113 HARV. L. REV. 29 (1999).

2. For a discussion of the idea of constitutional regimes, and for a brief description of the New Deal-Great Society regime, see Tushnet, supra note 1, at 34-36. A shorthand description of the concept of constitutional regimes is that they are reasonably stable sets of political and constitutional arrangements within which political actors determine policy based on their shared understanding of the regime's fundamental organizing principles. 
speculation about the implications of those innovations for the national government's power with respect to foreign affairs. ${ }^{3}$ Most of the speculation has been that the Court is about to-or at least should-engage in what I have called projects of restoration and revolution. That is, the Court will, or should, return to an understanding of the relation between the nation's power with respect to foreign affairs that prevailed before the New Deal-Great Society era.

According to the conventional understanding of the New DealGreat Society order, the national government had essentially plenary power over any matter fairly described as implicating the nation's foreign affairs. ${ }^{5}$ Congress rarely pressed the limits of this plenary power during the New Deal-Great Society era, ${ }^{6}$ but political actors agreed that Congress had broad power. That agreement may have conditioned the policy-making environment by making available for serious consideration proposals that would involve expansive exercises of power, thereby pushing policybargaining in an internationalist direction. Thus, acknowledging limits on Congress's constitutional authority with respect to foreign affairs would not only change dramatically our understanding of what Congress might do, but might also have real effects on policy outcomes.

I propose in this Essay a more modest perspective on the relation between the Court's new federalism doctrine and the constitutional regulation of the nation's conduct of foreign affairs. Focusing on international human rights, I argue that the Court's initiatives are likely to be rather small. This chastened ambition, as I have called it, results in part from the structure of politics in the current regime, but more from the accumulated weight of precedent and, even more, from the continuing importance of U.S.

3. Probably the most prominent such speculation is Curtis A. Bradley, The Treaty Power and American Federalism, 97 MICH. L. REv. 390 (1998) (arguing, inter alia, that the Court's doctrine dealing with foreign affairs should be harmonized with its new domestic federalism doctrine). For additional discussion, see infra notes 76-100 and accompanying text.

4. Mark Tushnet, What is the Supreme Court's New Federalism?, 25 OKLA. CITY U. L. REV. 927 (2000).

5. Another part of the conventional understanding was that within the national government the President had essentially plenary power with respect to such matters, even in the face of congressional disagreement. This aspect of the New Deal-Great Society constitutional order is not a focus of my concern here.

6. See, e.g., Barclays Bank PLC v. Franchise Tax Bd., 512 U.S. 298 (1994) (a case in which Congress did not exercise its power over foreign commerce to displace a controversial state tax). This contrasts with its actions in domestic matters, where it did exercise its powers quite expansively. 
government action in the international order. Section II of this essay outlines the place of foreign affairs in the New Deal-Great Society constitutional order, and the reasons for thinking that they will occupy a somewhat different place in the new constitutional order. Section III describes some problems where international human rights and domestic constitutional law intersect. Section IV then examines the Supreme Court's federalism doctrine and its application to foreign affairs generally and to the problems described in the preceding Part.

\section{FOREIGN AFFAIRS AND MODERN CONSTITUTIONAL ORDERS}

Harold Koh has described processes by which international legal norms are incorporated into the domestic legal order. ${ }^{7}$ I adapt his term to describe the incorporation of international policy concerns as well. ${ }^{8}$ After such concerns are incorporated and internalized in the policy-making process, they must be integrated with the remainder of constitutional law. The conventional wisdom about the way in which foreign affairs were integrated into the New Deal-Great Society constitutional order can be easily stated. The United States came to play a major role in international affairs, initially in World War II and then as the leader of anticommunist forces during the Cold War. ${ }^{9}$ A bipartisan consensus emerged supporting that role as traditionally isolationist segments of both major parties were displaced. The consensus was that the new U.S. role required maximum flexibility in developing international policies. ${ }^{10}$ The nation's power with respect to foreign affairs therefore had to be plenary. ${ }^{11}$ As Martin Flaherty puts it, the

7. See Harold Hongju Koh, Bringing International Law Home, 35 Hous. L. REV. 623, 642 (1998) (describing, inter alia, political and legal "internalization" of international norms).

8. For additional discussion of legal internalization, see text accompanying notes-infra.

9. For a discussion, see W. Michael Reisman, War Powers: The Operational Code of Competence, 83 AM. J. INT'L L. 777, 780-83 (1989).

10. For a discussion of the manner in which constitutional doctrine was transformed, stressing that the process took place over a long period and was not directly connected to the New Deal itself, see G. EDWARD WHITE, THE CONSTITUTION AND THE NEW DEAL 33-93 (2000).

11. Responding in part to Senator Bricker's proposals to amend the Constitution, the consensus came to accept the proposition that this plenary power was limited by the Constitution's individual rights provisions. See Reid v. Covert, 354 U.S. 1 (1957). For a discussion of the Bricker proposals, see DUANE TANANBAUM, THE BRICKER AMENDMENT CONTROVERSY:A TEST OF EISENHOWER'S POLITICAL LEADERSHIP (1988). 
New Deal, World War II, and "the emergence of the Soviet Union led to a rejection of formalist nineteenth-century understandings, fostering instead a regime that was executive-centered in terms of separation of powers, nationalist as a matter of federalism, and internationalist in general orientation." ${ }^{\text {12 }}$ Formalist doctrines, in which some matters might be categorically excluded from the foreign affairs power, were replaced by balancing tests that gave the government what seemed to be the appropriate degree of flexibility. ${ }^{13}$

With the collapse of the Soviet Union, "parochial doctrines reemerged. Domestically, 'states' rights' is no longer a segregationist slogan but once again constitutional doctrine. ${ }^{\text {.14 }}$ The declining threat of international crisis removed one source of nationalizing pressure. ${ }^{15}$ In Jack Goldsmith's terms, at least some of the international issues currently raising questions of domestic constitutional law "are from any perspective much less significant" than the ones arising from the Cold War. ${ }^{16}$ One of Goldsmith's examples is the Massachusetts law under which the state refused to contract with businesses that themselves did business in Myanmar (Burma). ${ }^{17}$ That he uses such an example is symptomatic of another feature of the modern constitutional order - the decay of consensus on what matters in international affairs. Supporters of the claim that international human rights matter a great deal have significant political leverage within the Democratic party, and rather less in the Republican party.. Similarly, the parties seem to disagree

12. Martin S. Flaherty, History Right? Historical Scholarship, Original Understanding, and Treaties as "Supreme Law of the Land" 99 COLUM. L. REV. 2095, 2095-96 (1999).

13. See Jack L. Goldsmith, The New Formalism in United States Foreign Relations Law, 70 U. COLO. L. REV. 1395, 1409 (1999) (asserting that "[t]he Court's traditional rule-like approach to the judicial foreign relations doctrines might have seemed unsatisfactory because any errors of under- or overinclusiveness were thought to be unacceptably costly in the Cold War world"). 14. Flaherty, supra note 12, at 2096.

15. See Curtis A. Bradley, A Nerw American Foreign Affairs Lawe?, $70 \mathrm{U}$. COLO. L. REV. 1089, 1105 (1999) ("The end of the Cold War era also is a likely factor in the shift away from foreign affairs exceptionalism, since there is now a reduced need for the national government to speak with one voice in international relations, and because many of the exceptionalism decisions ... clearly seem to be a product of the Cold War era."). See also Peter J. Spiro, Foreign Relations Federalism, 70 U. COLO. L. REV. 1223, 1241-46 (1999) (describing the historical Cold War context in which foreign affairs doctrine was shaped).

16. Goldsmith, supra note 13, at 1412.

17. See id. The Massachusetts law was held preempted by federal legislation in Crosby v. National Foreign Trade Council, 530 U.S. 363 (2000). 
systematically about the appropriate role in U.S. foreign policy of a generalized concern for human rights. ${ }^{18}$

In addition to these political elements, the institutional environment of modern international law differs in several ways from the institutional environment associated with the foreign affairs policy-making process during the New Deal-Great Society constitutional order. The participants in international law-making differ. Traditional international law involved the direct creation of binding rules in bilateral or multilateral treaties, while modern international law establishes free-standing law-making institutions to generate norms. ${ }^{19}$ Domestically, the process of participating in international law-making differs as well. Historically, what might be called ordinary interest groups, typically oriented to achieving material goals, were the major interest group participants in the domestic processes that fed into treaty-making. ${ }^{20}$ Now nongovernmental organizations with ideological commitments, interest groups, to be sure, but of a different sort, are important participants in the process, and some of these organizations operate across national borders.

These new features of the constitutional order suggest that the contours of constitutional doctrine might change as well. The Massachusetts Burma Law case may provide a hint of such changes. One doctrine associated with the New Deal-Great Society order was a strong presumption that the national power over foreign affairs preempted state legislation, even when Congress had not in fact directly exercised its power and even when the state legislation was not obviously incompatible with what Congress had in fact done. ${ }^{21}$ The Supreme Court might have decided the Burma Law

18. For example, the 2000 Democratic National Platform, available at <http://www.democrats.org/hq/resources/platform/platform.html> (last visited Mar. 1, 2001), "demand[s]" that "Congress pass the Convention to Eliminate All Forms of Discrimination Against Women," and asserts that "[w]e will continue to press for human rights, the rule of law, and political freedom." The 2000 Republican platform, available at < http://www.rnc.org/2000/2000platform8> (last visited Mar. 1, 2001), criticizes the Clinton administration's humanitarian interventions and mentions human rights in connection with Cuba, Chechnya, and Iran.

19. For a collection of essays on Traditional and Contemporary International Law, see INTERNATIONAL LAW: CLASSIC AND CONTEMPORARY READINGS (Charlotte Ku \& Paul F. Diehl eds., 1998).

20. Here I have in mind the interest groups associated with the negotiation of tax treaties and in litigation over the constitutionality of state taxes affecting corporations operating transnationally.

21. The strongest case supporting this presumption is Zschernig v. Miller, 389 U.S. 429 (1968). 
case by invoking this presumption. It did not. Instead, it adopted what appears to be a studiously neutral stance, applying ordinary principles of statutory interpretation with no concession in its interpretive approach to the fact that the state law implicated foreign affairs.

A political scientist might think that the Court's neutral approach resulted in part from some relatively novel characteristics of the Burma Law. State efforts to influence other nations' governments through their purchasing activities are a rather recent development. Perhaps more important, the Burma Law was the product of a new policy-making process, in which transnational non-governmental organizations have come to act in the way traditional interest groups did. ${ }^{23}$ These transnational NGOs differ from most traditional interest groups. Typically, the latter have some direct material interest in the legislation they seek ${ }^{24}$ while transnational NGOs typically assert only moral interests. ${ }^{25}$ Perhaps the New Deal-Great Society presumption in favor of preemption made sense to a Court accustomed to assessing legislation emerging from a policy-making process dominated by the traditional interest groups that were an integral part of that order. The new constitutional order might be skeptical about that process and adopt a state-favoring presumption against preemption. But, the new policy-making environment may have left the Court in a more neutral interpretive position.

According to Koh, international norms become sources of domestic law, ${ }^{26}$ but, as I have indicated, they are only one among

22. For my analysis of the case, see Mark Tushnet, Globalization and Federalism in a Post Printz World, 36 TULSA L.J. 11 (2000). I should note, however, that other scholars believe that what the Court did was actually inconsistent with its avowedly neutral interpretive stance. I believe that those scholars have not yet made their case, largely because to do so would require comparing the Court's performance in the Burma Law case with its performance in other preemption cases not involving foreign affairs, a task that these scholars have not yet undertaken.

23. But see Koh, supra note 7, at 647 (describing the role of transnational NGOs in the antislavery movement of the $1800 \mathrm{~s}$ ).

24. Of course they may also have moral interests, and almost always press their policies on public interest grounds. Nonetheless, the element of material interest is so common as to be a structural feature of traditional interest group lobbying.

25. Again, this is not to contend that transnational NGOs do not have, or at least are not supported by groups that have, material interests (labor unions supporting international human rights claims about working conditions being the obvious example), but only that the place of material interest is substantially smaller than in traditional interest groups.

26. See Koh, supra note 7. 
many such sources. They must be integrated into domestic constitutional law, harmonized with other doctrines. The New Deal-Great Society constitutional order harmonized foreign affairs to other provisions by giving foreign affairs primacy. ${ }^{27}$ Ordinarily foreign affairs policies might express the United States' national interest narrowly understood. Sometimes, however, those policies would adopt international norms. Even then the New Deal-Great Society constitutional order gave them primacy. The new constitutional order may treat international norms as on roughly the same plane as other sources of law. ${ }^{28}$ The project of integration would then become more complex. The next Section describes a few areas in which U.S. constitutional law will have to engage in that project.

\section{FEDERALISM AND INTERNATIONAL HUMAN RIGHTS LAW}

The project of integrating international legal norms and domestic constitutional law may be a large one once domestic constitutional law is not automatically subordinated to international norms. ${ }^{29}$ On some interpretations, the North

27. Critics refer, somewhat pejoratively I think, to "foreign affairs exceptionalism." See, e.g., Bradley, supra note 15, at 1104. Peter Spiro pointed out to me that the New Deal-Great Society constitutional order gave primacy to foreign affairs primarily, if not exclusively, with respect to policy concerns rather than constitutional ones.

28. See Goldsmith, supra note 13, at 1399, uses the term "underspecification" to refer to the problems that arise when a norm must be integrated into existing law, without clear guidance from the norm itself as to its place in domestic law. Goldsmith continues, "[E]ven if federal law is underspecified [that is, when integration is necessary]..., such controversy is no more serious than analogous controversies that arise all the time from underspecification of federal law in domestic contexts." Id.

29. I must express the discomfort I felt as a domestic constitutional lawyer reading arguments about the incorporation and integration of international legal norms into domestic constitutional law. The predominant view appears to be that the analytic work is completed upon establishing that some particular norm is in fact a norm of international law, sometimes on the ground that international legal norms by definition override contrary domestic ones. That would be true as well if the domestic processes by which international legal norms were integrated into domestic law made them hierarchically superior to other sources of domestic law. Such superiority may have (contingently) characterized the New Deal-Great Society constitutional order. But, plainly, it is not a necessary characteristic of the relation between international norms and constitutional law, including the constitutional law of federalism. It may be that the international legal norm prevails because it can be integrated into domestic constitutional law without alteration, but today establishing that proposition takes some arguments drawn from domestic constitutional law. 
American Free Trade Agreement authorizes determination of binding domestic law by an appellate body whose members do not have the guarantees of tenure required by Article III. ${ }^{30}$ Some have contended that the treaty banning the production of biological weapons authorizes searches within the United States that do not satisfy the Fourth Amendment's requirements. ${ }^{31}$

Two episodes involving the death penalty offer the opportunity to examine the integration of international human rights norms with the domestic constitutional law of federalism. The first is the celebrated Breard litigation. ${ }^{32}$ Breard was a national of Paraguay who was convicted in a Virginia court of capital murder and sentenced to death. ${ }^{33}$ The Vienna Convention on Consular Relations provides that foreign citizens detained by officials in another nation must be informed promptly of their right to contact their embassy. ${ }^{34}$ Breard did not receive that information. ${ }^{35}$ After his conviction Breard filed a petition for habeas corpus in federal court, arguing that the failure to comply with the Vienna Convention's requirements entitled him to relief from his conviction. ${ }^{36}$ In addition, Paraguay filed suit in the federal district court and in the Supreme Court against various Virginia officials, seeking an injunction against the execution. ${ }^{37}$ And, finally, Paraguay filed an action against the United States in the International Court of Justice, which promptly issued an order directing the United States to "take all measures at its disposal to ensure that Angel Francisco Breard is not executed pending the final decision in these

30. For contrasting views, see Demetrios G. Metropoulos, Constitutional Dimensions of the Nortb American Free Trade Agreement, 27 CORNELL INT'L L.J. 141 (1994) (arguing that the NAFTA dispute resolution violates Article III), and Justin Senior, Comment, The Constitutionality of NAFTA's Dispute Resolution Process, 9 FLA.J. INT'L L. 209 (1994) (arguing that the dispute resolution process is constitutional). See also A. Mark Weisburd, International Courts and American Courts, 21 MrCH J. INT'L L. 877, 892-900 (2000) (discussing Article III problems that might arise from a treaty authorizing international review of decisions by U.S. courts).

31. See, e.g., Ronald D. Rotunda, Constitutional Problems with Enforcing the Biological Weapons Convention, 61 CATO INST. FOREIGN POL'Y BRIEFING 1, 3.8 (Sept. 28, 2000).

32. See Breard v. Greene, 523 U.S. 371 (1998). Weisburd, supra note 30, at $879 \mathrm{nn} .7-8$, provides citations to the major academic commentaries on the Breard litigation.

33. See Breard, 523 U.S. at 373.

34. See id.

35. See id.

36. See id.

37. See id. 
proceedings." 38

All the suits failed. Breard's habeas corpus suit was rejected because he had failed to present his claim under the Vienna Convention to the state courts in an appropriate manner. ${ }^{39}$ Paraguay's suits failed because a foreign nation is not a "person" entitled by the relevant federal statute to sue state officials for constitutional violations, ${ }^{10}$ because the Convention did not clearly provide a private right of action in which a nation could vacate a conviction, ${ }^{41}$ and perhaps because the Eleventh Amendment barred suits against the state officials. ${ }^{42}$ Responding to the International Court of Justice's order of provisional measures, the U.S. Secretary of State wrote a letter requesting that Virginia's governor delay Breard's execution. ${ }^{43}$ The U.S. Department of Justice took the position in its briefs to the Supreme Court that such a request was the only "measure at its disposal" under U.S. constitutional law. The U.S. Supreme Court, after citing that letter, concluded, "If the Governor wishes to wait for the decision of the ICJ, that is his prerogative. But nothing in our existing case law allows us to make that choice for him. ${ }^{\text {s5 }}$

Virginia was also involved in the other case on which I focus. Jens Soering and his girlfriend conspired to kill her parents. ${ }^{46} \mathrm{He}$ fled to Europe. ${ }^{47}$ Responding to a request for extradition, Soering obtained a ruling from the European Court of Human Rights that Virginia's method of administering the death penalty was "cruel, inhuman, [or] degrading treatment" in violation of the European Convention on Human Rights, ${ }^{48}$ with the result that the British government could not comply with both the extradition request

38. Id. at 374 (quoting Order on Request for the Indication of Provisional Measures, 1998 I.C.J. Reports 248 (Apr. 9, 1998), from Concerning the Vienna Convention of Consular Relations (Paraguay v. U.S.), 1998 I.C.J. Pleadings 91 (Oct. 9, 1998)).

39. See id. at 375.

40. See id. at 378.

41. See id. at 377.

42. See id.

43. See id. at 378.

44. As the government brief put it, "our federal system imposes limits on the federal government's ability to interfere with the criminal justice systems of the States. The 'measures at [the United States'] disposal' under our Constitution may in some cases include only persuasion." Brief for the United States as Amicus Curiae at 51, Breard v. Greene, 523 U.S. 371 (1998) (No. 97-8214). 45. Breard, 523 U.S. at 378.

46. See Soering v. United Kingdom, 11 Eur. Ct. H.R. at 439 (1989).

47. See id.

48. 11 Eur. Ct. H.R. (ser. A), pp. 439, 478, P111 (1989). 
and the European Convention. The U.S. government then represented to the United Kingdom that Soering would not be prosecuted for capital murder in Virginia. ${ }^{49}$ Soering was then extradited and was prosecuted without facing the risk of capital punishment. ${ }^{50}$

Breard and Soering raise questions about the integration of international human rights norms and U.S. federalism. In particular, the cases implicate the two dimensions of the new constitutional order's federalism doctrine. ${ }^{51}$ The first dimension is a restriction on the subject-matter scope of congressional power; the second is a restriction on the methods Congress may use to carry out policies otherwise authorized by the Constitution. The Court has operated along the first dimension in invalidating the Gun-Free School Zones Act, ${ }^{52}$ the civil liability provisions of the Violence Against Women Act, ${ }^{53}$ and the Religious Freedom Restoration Act. ${ }^{54}$ In each case the Court held that the Constitution allows Congress to act only when it can properly invoke one of the powers enumerated in the Constitution, and that the power to regulate commerce among the several states or to implement the Fourteenth Amendment's substantive guarantees did not extend to the statutes in question. ${ }^{55}$ The Court has operated along the second dimension in defining the "anti-commandeering" principle, according to which Congress may not direct state legislative officials to enact or state executive officials to enforce legislation conforming to Congress's specifications. ${ }^{56}$

49. For a description of the U.S. government's representations, see Sanja Djajic, The Effect of International Court of Justice Decisions on Municipal Courts in the United States: Breard v. Greene, 23 HASTINGSINT'L \& COMP. L. REV. 27, 7980 (1999).

50. The U.S. Supreme Court has regularly denied review of claims that longterm detention on death row awaiting execution violates the Eighth Amendment's ban on cruel and unusual punishment. For the most recent case, see Knight v. Florida, 528 U.S. 990 (1999), with separate opinions by Justices Thomas and Breyer.

51. A third set of cases involving federalism limits the remedies available for violations of substantive norms otherwise properly imposed on the states. These are the so-called Eleventh Amendment cases. Notably, these cases do not implicate the substantive scope of the national government's power, which is my concern here.

52. See United States v. Lopez, 514 U.S. 549, 552 (1995).

53. See United States v. Morrison, 529 U.S. 598, 602 (2000).

54. See City of Boerne v. Flores, 521 U.S. 507, 511 (1997).

55. See Lopez, 514 U.S. at 551, 567-68; Morrison, 529 U.S. at 607, 618-19; City of Boerne, 521 U.S. at 536.

56. See Printz v. United States, 521 U.S. 898, 925-26 (1997); New York v. United States, 505 U.S. 144, 161 (1992). See also infra note 99. 
Breard and Soering indicate the ways in which a national obligation assumed under a treaty may have adverse effects on a state's ability to prosecute ordinary crime, an interest that the Court has occasionally invoked in explaining its subject-matter limitations on congressional power. ${ }^{57}$ In addition, the Vienna Convention appears to impose an obligation on state police officials to comply with a directive from the national government, an obligation that is in apparent tension with the anti-commandeering principle. $^{58}$

The Breard litigation was rushed, and reached the Supreme Court in an extremely awkward procedural posture. ${ }^{59}$ In addition, Breard's argument that Virginia's failure to comply with the Vienna Convention entitled him to relief from his conviction may well have been flawed on the merits. ${ }^{60}$ More interesting than Breard's personal claims are possible responses to the ICJ's Order of Provisional Measures. ${ }^{61}$ The ICJ ordered the U.S. government to "take all measures at its disposal." What measures were at the national government's disposal? In particular, could the U.S. government direct that Virginia forgo its prosecution because of the state's failure to comply with the Convention? To focus the discussion, suppose that Congress enacted a statute implementing the Convention with two basic elements. First, Congress directs all state police officials to ask the persons who they arrest whether they are foreign nationals and then to inform immediately those who are, of their rights under the Vienna Convention..$^{3}$ Second,

57. See, e.g., Printz, 521 U.S. at 927-28 (describing the diversion of investigative efforts from felony cases to background checks).

58. See Vienna Convention on Consular Relations, Apr. 24, 1963 (1970), 21 U.S.T. 77, 596 U.N.T.S. 261.

59. See supra text accompanying notes $41-42$.

60. The Convention could be read to provide a right to notice but not that the remedy for violating that right is the invalidity of any conviction later obtained.

61. Order on Request for the Indication of Provisional Measures, 1998 I.C.J. Reports 248 (Apr. 9, 1998) from Concerning the Vienna Convention on Consular Relations (Paraguay v. United States), 1998 I.C.J. Pleadings 91 (Oct. 9, 1998).

62. Order of Provisional Measures, 1998 I.C.J. Reports at 258.

63. After the Breard litigation concluded, the U.S. government apologized to the government of Paraguay and distributed information about the Vienna Convention's requirement to police agencies throughout the country. For the former, see Brief for the United States as Amicus Curiae at 10, Breard v. Greene, 523 U.S. 371 (1998) (No. 97-8214); for the latter, see Marion Nash, Contemporary Practice of the U.S. Relating to International Law, 92 AM. J. INT'L L. 243, 243-45 (1998) (quoting Consular Notification and Access: Instruction for Federal, State, and Local Law Enforcement and Other Officials Regarding Foreign Nationals in the U.S. 
Congress provides that no person entitled to such information can be prosecuted if the information was not given, and that convictions obtained when the information was not given are void. Would such a statute be constitutional? Similarly, one can ask where the national government gets the authority to represent to foreign nations that state governments will not invoke their ordinary criminal processes, including the option of the death penalty.

\section{FEDERALISM, INTERNATIONAL HUMAN RIGHTS, AND THE NEW CONSTTTUTIONAL ORDER}

\section{A. A Framework for Evaluating the Need for Constitutional Doctrine \\ Much existing discussion of U.S. federalism and international human rights proceeds by hypothesizing that the United States has entered into some international agreement that requires national}

and the Rights of Consular Officials to Assist Them, U.S. DEPT. OF STATE, PUB. No. $10518(1998))$.

64. The doctrine of speciality permits post-extradition limitations on the power to prosecute. Most reported specialty cases appear to involve limitations on the power of the U.S. government to prosecute after extradition, but state courts assume that they must enforce limitations pursuant to representations by the U.S. government. See, e.g., Washington v. Pang, 940 P.2d 1293 (Wash. 1997) (addressing the proper interpretation of the doctrine of specialty while assuming its applicability). I note as well that it seems to be assumed that the doctrine applies to limitations on post-extradition punishment, or at least to representations that the death penalty will not be invoked. Additionally, a federal statute provides: "Whenever any person is delivered by any foreign government to an agent of the United States, for the purpose of being brought within the United States and tried for any offense of which he is duly accused, the President shall have power to take all necessary measures . ... for [the accused person's] security against lawless violence." 18 U.S.C. $\$ 3192$ (1994). Although the context clearly suggests a concern for protecting against mob violence, the term "lawless violence" might reasonably be interpreted to refer to a state government's refusal to comply with the doctrine of specialty. Carlos Vázquez, Professor of Law at the Georgetown University Law Center, suggested to me that the extradition of a particular individual after a representation by the United States that triggers the doctrine of specialty might be regarded as an executive agreement made pursuant to the overarching extradition treaty, and as an executive agreement, it would bar states from acting in a manner inconsistent with the agreement under United States v. Belmont, 301 U.S. 324 (1937), and United States v. Pink, 315 U.S. 203 (1942). Finally, the doctrine of specialty is available as a defense to a criminal prosecution, and is therefore applied by state courts. According to the Supreme Court, the anti-commandeering principle does not bar the national government from imposing obligations on state judges. See New York v. United States, 505 U.S. at 178-79 (distinguishing Testa v. Katt, 330 U.S. $386(1947))$. 
action that intrudes on matters of state concern, whether by taking over a subject-matter ordinarily regulated by state governments or by commandeering state officials. For example, authors ask whether the U.S. Constitution would preclude the nation from entering into an international agreement to ban the imposition of death sentences on those who were juveniles when they committed their crimes. But, proceeding by hypothetical may be particularly misleading today, in the new constitutional order because such agreements are exceedingly unlikely to be adopted.

I begin with what should be obvious: Over the past generation the treaty-makers have been quite reluctant to endorse expansive exercises of the treaty power. They have routinely added a "federalism" declaration to international agreements dealing with human rights, and sometimes have expressly disclaimed the applicability of particular treaty provisions. ${ }^{65}$ If anything, this practice is likely to strengthen in the new constitutional order.

The political origins of these "federalism" limitations are reasonably clear. The basic features of the national governing process over the past generation have been divided government and increasingly hostile divisions between the Democratic and Republican parties. Acceding to the international agreements in question has been a priority of the human rights and internationalist wings of the Democratic party. ${ }^{66}$ They picked up

65. For a recent discussion and defense of the practice of making federalism and more specific reservations to U.S. ratification of international treaties, see Curtis A. Bradley \& Jack L. Goldsmith, Treaties, Human Rights, and Conditional Consent, 149 U. PA. L. REV. 399 (2000). On a technical level, federalism declarations might not preclude Congress from enacting constitutionally questionable legislation and may not be judicially enforceable. But, more important, the federalism declarations typically state that the national government will implement the treaty to which the declaration is attached only in areas of traditional national authority. Thus, on a political level, the government could defend any treaty-based legislation on the ground that it did not go beyond the scope of traditional national authority. Nonetheless, a Senate insistent enough on federalism to require that a federalism declaration be attached to a treaty is unlikely to approve treaty-based legislation raising federalism concerns.

66. For example, the Carter administration submitted five international human rights agreements to the Senate (the International Covenant on Civil and Political Rights [hereinafter Covenant on Civil and Political Rights]), the International Covenant on Economic, Social, and Cultural Rights, the Convention for the Elimination of All Forms of Racial Discrimination (CERD), the American Convention on Human Rights, and the Convention on the Elimination of All Forms of Discrimination Against Women (CEDAW)); the Reagan administration submitted two (the Genocide Convention and the Convention Against Torture and Other Cruel, Inhuman or Degrading 
some support from the residual internationalist wing of the Republican party, but Republicans have been significantly more skeptical of international institutions than Democrats. Treaties require agreement from two-thirds of the Senate, a level that cannot be reached without substantial bipartisan support in a Senate that has become increasingly divided along partisan lines even on foreign affairs issues. The federalism declarations are the price Democrats have to pay to obtain enough votes from Republicans to adopt the treaties. ${ }^{67}$ Even sharper divisions are present in the new constitutional order, making it quite unlikely that the United States will enter into treaties or international agreements raising serious federalism questions. ${ }^{68}$

$\mathrm{New}$, problematic agreements may be rare. But what of existing agreements? Some agreements made during the New Deal-Great Society constitutional order might raise questions that were not taken seriously at the time they were entered, but would be taken seriously in the new constitutional order. ${ }^{69}$ This could occur in two ways. First, the existing agreements might be interpreted expansively. The Supreme Court's actions in the Breard litigation suggest that the Court is unlikely to provide such interpretations. Its opinion was shot through with skepticism about the claim that the Vienna Convention should be interpreted to provide any of the many grounds for relief Paraguay and Breard found in the Convention. ${ }^{70}$ Nor is it likely that today's Congress would seize upon an existing treaty as the basis for legislation it could not otherwise enact. ${ }^{91}$ Second, the existing agreements might be

Treatment or Punishment [hereinafter Torture Convention]); the Bush administration submitted two (the Torture Convention and the Covenant on Civil and Political Rights); the Clinton administration submitted two (CERD and CEDAW).

67. The same dynamic occurs in connection with ordinary legislation, where the requirement of support in both houses of Congress replaces the requirement of two-thirds support in the Senate.

68. Treaty proponents may be able to move some treaties forward by gaining agreement from some states to accept the treaty's requirements and agreement from the negotiating partners that application of the treaty's requirements everywhere in the United States is unnecessary. (I am grateful to my colleague John Jackson for pointing out this possibility to me).

69. See Tushnet, supra note 1, at 75 (distinguishing between the Supreme Court's willingness to aggressively review old statutes and Congress' reluctance to enact new ones).

70. See Breard v. Greene, 523 U.S. 371, $377-78$ (1998).

71. See Gerald L. Neuman, The Global Dimension of RFRA, 14 CONST. COMMENT. 33, 50-51 (1997) (suggesting that the Covenant on Civil and Political Rights might be a source of congressional authority to enact the Religious Freedom Restoration Act (RFRA)). For the Congressional response to the 
unambiguous. ${ }^{72}$ The Vienna Convention, for example, really does command state police officials to take particular actions; the ambiguities the Court found in the Convention went to remedy, not to the underlying obligation..$^{73}$ As we will see, however, the unambiguous agreements raising serious federalism question have a rather strong pedigree. The Court could enforce federalism limitations only by engaging in a revolutionary transformation of constitutional doctrine. But it need not do so. The existing agreements that unambiguously raise federalism questions are, I believe, rather few in number and these exceptional cases can be preserved without threatening any serious federalism concerns the Court might have in the new constitutional order. ${ }^{74}$

In the new constitutional order, then, the Supreme Court is not likely to have any need to develop constitutional doctrines dealing with power to regulate international affairs that limit national power in the name of federalism. Modesty, not revolution, is the order of the day.

\section{B. Federalism Limitations on the Power Over Foreign Affairs}

Applying subject-matter limitations and the anticommandeering principle in the context of international relations is likely to prove quite difficult. A subject-matter limitation

Supreme Court's invalidation of the RFRA, relying on the commerce and spending powers, see Religious Land Use and Institutionalized Persons Act of 2000, Pub. L. No. 106-274, 114 Stat. 803.

72. Again, coming to the matter as an outsider, I was struck by the existence of interpretive ambiguity with respect to the doctrine of specialty in Soering, both with respect to its application to state-level prosecutions and with respect to representations about the application of the death penalty. If interpretive ambiguity exists there, unambiguous provisions raising serious federalism questions must be exceedingly rare.

73. See Breard, 523 U.S. at 376.

74. Carlos Vázquez has pointed out that many existing treaties have aspirational provisions that, while not enforceable without supporting legislation, might be invoked to justify legislation not otherwise within an enumerated power. See Carlos Manuel Vázquez, Breard, Printz, and the Treaty Power, 70 U. COLO.L. REV. 1317, 1339 n.75 (1999). He also points out that the treaty that was the basis for upholding the statute in question in Missouri $v$. Holland, 252 U.S. 416 (1920), provided that the United States would propose appropriate legislation, not that it would enact such legislation. Vázquez suggests that Holland might be limited by denying Congress the power to enact statutes based on such precatory provisions. I wonder, however, whether this makes too much of the difference between an obligation assumed by the national government to propose legislation and an obligation to enact it: Why would a treaty partner accept the former without believing that it entailed the latter? 
appropriate to the context of international relations would have to accommodate two concerns: the national interest in conducting international affairs, and federalism. The Court's federalism doctrine provides only hints at what such an accommodation might look like. Those hints suggest that the accommodation might place in doubt national actions that go back to the early Republic. Applying the anti-commandeering principle to international affairs would have similar effects. The Court has supported the anticommandeering principle by pointing out that Congress has only recently attempted to direct state officials to enforce national policy. ${ }^{75}$ That argument seems unavailable with respect to national power over international affairs. Finally, the Court's articulation of the anti-commandeering principle allows a number of escape hatches, some of which are rather clearly applicable to the Breard and Soering litigation.

\section{Subject-Matter Limitations}

The Court has confronted the issue of subject-matter limitations in connection with two discrete grants of power to Congress, the Commerce Clause and Section Five of the Fourteenth Amendment. The doctrine emerging from the Commerce Clause opinions is that Congress has power to regulate commercial activities that, in the aggregate, have a substantial effect on interstate commerce, but may not regulate non-commercial activities having the same aggregate effect. ${ }^{\prime 6}$ The Court's rationale for the distinction between commercial and non-commercial activities is that some line must be drawn to ensure that the commerce power does not give Congress plenary authority to regulate whatever a majority decides to regulate, ${ }^{77}$ and that the language of the Commerce Clause supports drawing the line between commercial and non-commercial activities. ${ }^{78}$ The Section Five decisions hold that Congress may enact legislation enforcing the guarantees of the Fourteenth Amendment's first section to the extent that the legislation is a proportionate response to demonstrated violations of those

75. See Printz v. United States, 521 U.S. 898, 917-18 (1997).

76. See United States v. Morrison, 529 U.S. 598 (2000).

77. See Glenn H. Reynolds \& Brannon P. Denning, Lower Court Readings of Lopez, or What If the Supreme Court Held a Constitutional Revolution and Nobody Came?, 2000 WIs. L. REV. 369, 378 (2000), describing this as the "noninfinity principle," that "any justification for congressional power must not be one that would undermine the very notion of enumerated powers."

78. See Board of Trustees of the Univ. of Alabama v. Garrett, 531 U.S. 356 (2001); Morrison, 529 U.S. at 598; City of Boerne v. Flores, 521 U.S. 507 (1997). 
guarantees. 79

These rules are of course tied to the particular constitutional provisions at issue. The Commerce Clause opinions, however, have another theme. The Court explained the importance of interpreting constitutional provisions as placing limits on Congress's powers by emphasizing that more expansive interpretations would license Congress to act in areas traditionally regulated primarily by the state. Those areas include education, ordinary crime, and land use control. ${ }^{80}$ This suggests that the Court might be interested in developing a subject-matter limitation directed not at the Constitution's enumerations of power, but rather at what used to be called the reserved powers of state governments.

These two approaches to subject-matter limitations will be difficult to develop in the context of Congress's power in international affairs. One problem is that the Court's federalism decisions have been concerned with what it characterized as innovative exercises of congressional power. For example, it used the fact that Congress had only recently begun to commandeer state executive officials in support of the anti-commandeering rule. ${ }^{81}$ But, treaties in which the U.S. government agreed to legal rules that, according to contemporaneous understandings, it could not otherwise enact go back to the early Republic. ${ }^{2}$ Even more, the Constitution unambiguously gives Congress the power to "define and punish ... Offences against the Law of Nations," which might be the subject of ordinary state criminal law. Professor David Golove notes early treaties overriding state laws barring aliens from owning real property, which might fall within the present Court's area of "land use regulation," despite the fact that

\section{See cases cited supra note 78.}

80. On education, see United States v. Lopez, 514 U.S. 549 (1995) (criticizing the implication of alternative views that would allow Congress to "mandate a federal curriculum for local elementary and secondary schools"); on ordinary crime, see Morrison, 529 U.S. at 615 (noting that alternative views would allow Congress to regulate murder); on land use control, see Solid Waste Agency v. Army Corps of Engineers, 121 S. Ct. 675, 684 (2001) (referring to the states' "traditional and primary power over land and water use").

81. See Printz, 521 U.S. at 917-18.

82. See Beth Stephens, Federalism and Foreign Affairs: Congress' Power to "Define and Punish... Offenses Against the Law of Nations," 42 WM. \& MARY L. REV. 447 (2000).

83. U.S. CONST. art. I, \& 8, cl. 10. See generally David M. Golove, TreatyMaking and the Nation: The Historical Foundations of the Nationalist Conception of the Treaty Power, $98 \mathrm{MICH}$. L. REV. 1075, 1149-1210 (2000) (describing treaties entered into during the early Republic and ante bellum periods, as well as contemporaneous political and academic commentary). 
no one at the time thought that Congress had a general power, independent of its treaty-making power, to prescribe rules of real property law applicable in the states. ${ }^{84}$ Professor A. Mark Weisburd, describing treaties upheld by the Supreme Court that overrode state laws regulating inheritance of lands by aliens, suggests that "regulation of ... those subjects would even today be difficult to bring within the powers of Congress described in Article I of the Constitution. ${ }^{85}$

What shape might a doctrine limiting the Treaty Power take? ${ }^{86}$ One might think that just as regulation premised on the Commerce Clause must target truly commercial activities, so regulation premised on the Treaty Power or other international affairs powers must target subjects truly appropriate for international agreement. ${ }^{87}$ The problem with this suggestion is that it is quite difficult to identity subject that are not appropriate for international agreement.

The difficulty comes in two forms. First, in a globalized world the line between domestic matters and international ones is increasingly difficult to draw-far more difficult than drawing the

84. See Golove, supra note 83 , at $1157-88$ (describing the controversy over the Jay Treaty between the United States and Great Britain, which contained a provision allowing British subjects to own real property in the states, thus overriding the common law rule allowing forfeiture of real property owned by aliens). I note that the federal courts followed state common law on real property even during the era of Swift v. Tyson. See, e.g., Jackson v. Chew, 25 U.S. (12 Wheat.) 153 (1827).

85. Weisburd, supra note 30, at 900 (discussing Chirac v. Chirac, 15 U.S. (2 Wheat.) 259 (1817), and Hauenstein v. Lynbam, 100 U.S. 483 (1879)).

86. The suggestion that federalism limitations are conceptually inappropriate with respect to foreign affairs rattles around in the literature. Relying on United States v. Curtiss-Wright Export Corp., 299 U.S. 304 (1936), these authors suggest that power over foreign affairs was never lodged in the states, which therefore could not "reserve" any aspect of foreign affairs power from the Constitution's delegations to the national government. See, e.g., Chad Thornberry, Comment, Federalism vs. Foreign Affairs: How the United States Can Administer Article 36 of the Vienna Convention on Consular Relations Within the States, 31 MCGEORGE L. REV. 107, 139 (1999); Thomas Healy, Note, Is Missouri v. Holland Still Good Lawe? Federalism and the Treaty Power, 98 COLUM. L. REV. 1726, 1748-50 (1998). The argument could be supplemented by observing that the Court adopted a related view in U.S. Term Limits v. Thornton, 514 U.S. 779 (1995). But, as one author observes, "One objection to this position is that it ... leaves the treaty power virtually unlimited." Healy, supra, at 1750 . If accepted, it would terminate the inquiry in which I am engaged here. In addition, adopting the position would be an aggressive assertion of national authority, in an era when the doctrinal trend is in the other direction.

87. See LOUIS HENKIN, FOREIGN AFFAIRS AND THE CONSTITUTION 140-41 (1972) (describing cases supporting such a limitation). 
line between commercial and non-commercial activities. ${ }^{88}$ As Professor Jack Goldsmith puts it, the difficulty of identifying U.S. foreign relations interests

is exacerbated by the waning of the distinction between domestic and foreign affairs. . . . In truth there is no definitive way of divining the U.S. foreign relations interest in a particular context or the manner in which this interest would be best accommodated. The Constitution gives these tasks primarily to the political branches that have the expertise and structure to perform them relatively well. ${ }^{89}$

Second, and probably more important, determining what is a matter for international agreement is not a unilateral decision made by the United States; it is a bilateral or multilateral one made in negotiations with other nations not necessarily concerned about U.S. domestic arrangements. So, for example, U.S. negotiators could come to the table with proposals that, in U.S. constitutional terms, might deal solely with matters that are uncontroversially within the scope of the Treaty Power, such as international trade or the international rendition of fugitives from prosecution by the United States. The negotiating partners might see this as an occasion for raising other issues. For example, they might take the position that they will agree to extradite those charged with federal money-laundering offenses only if the United States agrees to prohibit the execution of juvenile offenders charged in both federal and state courts. ${ }^{90}$ The U.S. treaty-makers-the President and the Senate-might agree to this proposal because they think the trade-off

88. See Bradley, supra note 3 , at 451-52 ("Today, almost any issue can plausibly be labeled "international."). Bradley continues, "[E]ven if there were a workable distinction in theory between international and domestic matters, it seems unlikely that U.S. courts would feel competent to contradict the political branches on this issue. It is far from clear, for example, what standard the courts could use to draw such a line." Id. at 453.

89. Goldsmith, supra note 13 , at 1416.

90. The national government clearly has the power to eliminate the juvenile death penalty in federal prosecutions, and has done so. 18 U.S.C. $\$ 3591$ (a) (1994). In the unlikely event that a negotiating partner insisted only that the juvenile death penalty be eliminated in state prosecutions, the federal negotiators might be more willing to concede than if they themselves had to forgo executing juvenile offenders. We might develop a doctrine that treaty provisions must deal even-handedly with the state and national governments, although I am skeptical about the possibility of developing a useful standard for determining when a provision operates in an even-handed way, and more skeptical about the need for a doctrine to guard against what seems to me a quite remote possibility. 
is worth it. Standing alone, the ban on the execution of juvenile offenders might not be a matter appropriate for international agreement, but the extradition issue clearly is. ${ }^{91}$ It is hard to understand why U.S. negotiators' hands should be tied when they seek to accomplish what all would concede are appropriate foreignpolicy objectives.

The foregoing example suggests the difficulty with the other approach to subject-matter limitations, carving out enclaves where only the states may regulate. One can readily devise scenarios in which the treaty-makers can accomplish concededly national objectives only by trading off some matters otherwise within the control of the states. For example, in the middle of a trade negotiation one of the trading partners says, "Well, we'll concede to you and allow the distribution in our country of biotechnologically enhanced food products from the U.S., although our people are going to be pretty upset about that. To offset their concern, though, in exchange you've got to stop executing juvenile offenders anywhere in the United States." As Professor Weisburd puts it, the United States enters negotiations with other nations "because it wants something from the other party or parties to the treaty, not because it seeks to use the treaty as a mechanism for domestic regulation," but "[d]omestic effects may be inevitable." It is implausible to impute to the Framers, or to any reasonable manner of constructing a national government, an interest in creating a structure that bars the national government from achieving national objectives in a manner that interferes with state prerogatives, when compelled to do so by its negotiating partners. ${ }^{93}$

The preceding argument also responds to the Court's expressed concern that constitutional doctrine must not authorize Congress

91. Mari Matsuda suggested in conversation that one could defend the position that the treaty power had no subject-matter limits even in the absence of explicit trade-offs. The U.S. treaty-makers could reasonably take the position that their bargaining position in a range of negotiations is strengthened by a perception among the negotiating partners that the United States is a law-abiding nation that honors international human rights norms. On this argument, even a free-standing treaty banning the death penalty for juvenile offenders would be a permissible exercise of the treaty power because adopting such a treaty would enhance the U.S. position in other negotiations about matters that unquestionably deal with matters of international concern.

92. Weisburd, supra note 30, at 921.

93. Again, the bi-or multilateral nature of foreign affairs distinguishes these negotiations from policy-making in a purely domestic context, where only Congress and the President decide what policies to pursue. In the treaty context, the U. S. treaty-makers initially decide on the nation's preferred policies, but they then must respond to counter-proposals by other nations. 
to do whatever its members think is wise policy, without regard to the source of their power to do good things. The Court's concern arises from the perception that Congress may act on its own, to do what it wants. The treaty context comes close to eliminating the possibility of unilateral action by Congress or the treaty-makers: national law-makers cannot do whatever they want, but only what other nations require them to do in order to extract from those other nations an agreement to do something in the U.S. national interest. The bargaining context, that is, sets the limits on Congress's unilateral action that the Court has sought through constitutional doctrine in the purely domestic context.

Professor Curtis Bradley has suggested one final subject-matter limitation. Under his proposal, Congress's power in international affairs, and in particular the treaty power, would not be an independent source of national authority. ${ }^{94}$ That is, no law could survive a federalism-based challenge unless its defenders could identify some source of congressional power other than the treaty power that is sufficient to authorize the statute. Professor Bradley's proposal is reminiscent of controversies in an earlier era over whether the Spending Clause was an independent source of national power, or whether instead Congress could appropriate money to achieve objectives determined only by some other enumerated power. The Supreme Court rejected the latter proposition, ${ }^{95}$ thus avoiding the problem that the alternative interpretation would have rendered the Spending Clause redundant. Redundancy is something of a problem in connection with Professor Bradley's proposal as well, because it would not authorize the national government to do anything domestically that it could not do anyway. ${ }^{96}$ Professor Bradley points out, however, that his proposal would not make the Treaty Power completely redundant, because it would authorize the national government to enter into agreements that would bind it internationally. Any breaches would be subject to international sanction. Note, however, that Professor Bradley's proposal means that the United States simply cannot comply with some provisions in international agreements the Constitution allows it to make. It is only a slight exaggeration to say that, under his proposal, the nation would be in violation of its international obligations at the moment it entered the agreement. Again, it is difficult to understand why one would design a constitution having that shape. A requirement that international agreements deal with matters

94. See Bradley, supra note 3, at 456.

95. See United States v. Butler, 297 U.S. 1 (1936).

96. Of course the procedures for adopting treaties and statutes differ. 
truly appropriate for international agreement, or a rule that the Treaty Power was not an independent source of domestic authority, could act as a bar to what might be called sham treaties. Such treaties are agreements ginned up by the U.S. treaty-makers simply to accomplish something they could not accomplish under any other power. ${ }^{97}$ One must imagine U.S. officials approaching some foreign partner, saying, "Look, could you do us a favor? We want to do something, (for example, regulate land use, or eliminate the death penalty for juveniles) that the Supreme Court won't let us do on our own. But if you sign on to an agreement that obligates us to do it, then everything would be hunky-dory under our Constitution." Perhaps there is a reason to construct constitutional doctrine to guard against such a remote possibility. ${ }^{98}$ Doctrines, though, have a tendency to expand beyond their rationales, and the risk of doctrinal creep probably exceeds the risk that the United States would negotiate sham treaties, in which case it would be better not to create a doctrine whose sole function is to bar sham treaties. ${ }^{99}$

In sum, it is quite hard to devise a reasonable subject-matter

97. Professor Golove, while criticizing the view that there are subject-matter limits on the treaty power, agrees that sham treaties cannot be enforced domestically against federalism objections. See Golove, supra note 83, at 1287 ("[T] he purpose of a treaty cannot be to adopt domestic standards just because the President and Senate believe them to be laudable."). See also HENKIN, supra note 87 , at 143 ("A treaty ... must be a bona fide agreement between states, not a 'mock marriage', nor a unilateral act by the United States to which a foreign government lends itself as an accommodation.....).

98. A somewhat more realistic possibility is a treaty whose domestic implications are strongly favored by the U.S. negotiators even though those implications are otherwise beyond the national government's power. The negotiators might then make larger concessions to the negotiating partners. A doctrine responsive to this concern would have to allow U.S. negotiators to agree to such provisions if they extracted "enough" in exchange, and pretty clearly would not be an attractive one for courts to administer.

99. I note another difficulty with the concern for sham treaties. Why would the negotiating partner simply do the U.S. treaty-makers a favor? They might see the U.S. offer as an opportunity to extract something in exchange. And, if that something is an appropriate subject for international agreement, such as a trade concession, we would again be in the position of having an agreement part of which is within the nation's power and part of which is (by hypothesis) not. As argued above, such mixed agreements would almost certainly survive constitutional scrutiny. For completeness, I note the possibility of a doctrine condemning treaties as shams where the international component in a mixed agreement was simply a facade for the treaty's true goal. Again, the possibilities that the treaty-makers would enter such agreements, and that the courts would be able reliably to identify them, are so small that developing a doctrine along these lines seems inadvisable. 
limitation on Congress's power in the international domain. Even in the new constitutional order, an agreement to eliminate the juvenile death penalty should be upheld. ${ }^{100}$ The United States is unlikely to enter into such an agreement.

\section{The Anti-Commandeering Principle}

There is an obvious objection to the main argument in the preceding section. Suppose the negotiating partners demanded that the U.S. government enact, not a law impermissible for federalism reasons, but a law violating the First Amendment. ${ }^{101}$ The New Deal-Great Society order accepted the proposition that the foreign affairs power was limited by the Constitution's protections of liberty. ${ }^{102}$ But, if the United States can override federalism concerns to achieve its foreign policy goals, why can it not override the Bill of Rights for the same reason?

One answer may simply be that the New Deal-Great Society constitutional order accepted a sharp distinction between individual liberties, enumerated in the Constitution, and what Justice Oliver Wendell Holmes called the "invisible radiation" of the Tenth Amendment. ${ }^{103}$ Another answer may be that the Treaty Power is indeed limited by federalism concerns, conceptualized as arising independent of the substantive scope of the Treaty Power. ${ }^{104}$ The issue then becomes one of identifying an appropriate federalism doctrine limiting, not just the Treaty Power, but all enumerated powers. At present the only candidate for such a doctrine is the anti-commandeering principle.

The Vienna Convention's requirement that police officials advise foreign nationals of their rights under the Convention seems a straight-forward example of commandeering pursuant to a treaty. ${ }^{65}$ Other treaties might direct state officials to comply with

100. Should here is both predictive and normative.

101. For example, a law bringing the United States in line with the international consensus that hate speech should be illegal could possibly violate the First Amendment (to the extent that such hate speech laws are unconstitutional).

102. See HENKIN, supra note 87 , at 254-66 (describing the liberty-based limitations on the foreign affairs power).

103. See Missouri v. Holland, 252 U.S. 416, 434 (1920).

104. One formulation is that subject-matter limitations identify internal limits on each enumerated power, limits that are specific to each such power, while individual-rights limitations are external to all the enumerated powers and cut across them all.

105. See Vázquez, supra note 74, at 1339 (describing the Convention's requirements as commandeering); Healy, supra note 86 , at 1746 (same). 
international human rights norms in ways requiring that they act rather than refrain from acting. ${ }^{106}$ Similarly, treaties might require that effective remedies be provided for violations of human rights. Creating such remedies might require legislation. ${ }^{107}$ Do these possibilities raise constitutional questions?

The Court's anti-commandeering decisions describe a quite limited exception that might be applicable to the Vienna Convention problem, though not to the others. The exception, described by Justice O'Connor and not disclaimed by the Court, would allow Congress to require state officials to compile information and report that information to federal officials. ${ }^{108}$ The decisions do not provide a justification for this exception. ${ }^{109}$ The Court asserted that it lacked the capacity to determine whether congressional requirements were too burdensome, ${ }^{110}$ so it cannot be that information-compilation does not impose real burdens on state officials. The most prominent functional reason the Court offered

106. I believe that there is an analytic problem lurking in the Court's apparent distinction between impermissible affirmative commandeering and permissible negative commandeering through preemption of state authority. For a discussion, see Tushnet, supra note 22, at 27. For present purposes, however, I accept the proposition that affirmative commandeering is impermissible but preemption is acceptable. But note Vázquez, supra note 74 , at 1347-48, 1350, uses Asakura v. Seattle, 265 U.S. 332 (1923), which upheld a treaty provision (from the Treaty on Commerce and Navigation, Feb. 21, 1911, U.S.-Japan, 37 Stat. 1504), that effectively required the city to consider license applications from Japanese citizens, to illustrate the proposition that "it is notoriously difficult to draw the line between affirmative and negative obligations."

107. According to the Supreme Court, the anti-commandeering principle would not be implicated if the treaties required only that state courts provide enhanced remedies within a general remedial framework already created by state law. See New York v. United States, 505 U.S. 144, 1778-79 (1992) (distinguishing Testa v. Katt, 330 U.S. 386 (1947), on the ground that the Supremacy Clause, directed specifically at state judges, allows them to be "commandeered" to enforce national law).

108. See Printz v. United States, 521 U.S. 898, 936 (1997) (O’Connor, J., concurring) (noting that the Court "refrains from deciding whether ... purely ministerial reporting requirements imposed by Congress on state and local authorities pursuant to its Commerce Clause powers are ... invalid," and referring to a federal law requiring reporting missing children to the Department of Justice).

109. The Court's analysis is expressly formalist, meaning in this context that the Court does not provide functional justifications for large parts of its doctrine. The information-compilation exception might be a formalist exception to a formalist doctrine, in which case there is little to say about it. See also Tushnet, supra note 22, at 30-32 (describing the Court's formalism and the way in which it limits the possibilities of reasoned analysis of the doctrine's contours and implications).

110. See Printz, 521 U.S. at 932-33. 
for the anti-commandeering doctrine is that commandeering diffuses political responsibility by making it unclear to citizens whether they should complain to local officials or to their representatives in Congress about some action they dislike. ${ }^{111}$ Commentators have questioned the cogency of this argument, ${ }^{112}$ but perhaps it explains why Congress may require state officials to compile information. The Court might believe that few citizens are likely to complain about state officials' efforts to obtain the information Congress requires, or that Congress has asked state officials merely to assemble in a form Congress requires information they already have obtained for their own purposes. I have my doubts about these factual propositions, but something like them must underlie a functional explanation of the exception to the anti-commandeering doctrine.

Perhaps Congress might require notification as well as information-compilation. ${ }^{119}$ Notification is, in one sense, simply information-compilation in reverse: Instead of asking someone for information, the police officials provide information to that person. And yet, the Court's functional concerns seem to come into play here. Providing the required information might be burdensome, particularly when the police officials must locate a consular official who might be far away. ${ }^{114}$ Obviously the person receiving the information is unlikely to complain. But what about the victims and their families? Notifying a criminal suspect of his or her rights is controversial when the notification is required by the Court's interpretation of the U.S. Constitution, because, critics think, it interferes with the ability of the government effectively to enforce the criminal law. Might not notification required by a treaty be at least as controversial? Describing the problem after a failure to notify has occurred, one commentator observes that executive officials face "a difficult decision .... -whether to adhere to an international obligation that most of their constituents probably

111. See New York, 505 U.S. at 182-83.

112. See, e.g., Evan H. Caminker, State Sovereignty and Subordinacy: May Congress Commandeer State Officers to Implement Federal Lawe?, 95 COLUM. L. REV. 1001, 1068-74 (1995); Roderick M. Hills, Jr., The Political Economy of Cooperative Federalism: Why State Autonomy Makes Sense and "Dual Sovereignty" Doesn't, 96 MICH. L. REV. 813, 824-31 (1998); Vicki C. Jackson, Federalism and the Uses and Limits of Law: Printz and Principle?, 111 HARV. L. REV. 2180, 220005 (1998).

113. Of course an exception for notification could be an additional formalist exception to a formalist doctrine.

114. See Thornberry, supra note 86, at 134-35 (describing the burdens notification might impose). 
did not know of or understand, or whether to adhere to their states' criminal justice concerns. . . ${ }^{115}$ The public might well project the same conflict back to the time when notification is actually given. The argument from diffusion of political responsibility in controversial settings seems no less powerful here than in the cases the Court decided. ${ }^{\mathrm{fl}}$

Perhaps one might conceptualize a notification requirement somewhat differently. As noted earlier, the Court's anticommandeering doctrine applies to efforts by Congress to commandeer state legislative and executive officials, but the Court allows Congress to commandeer state judicial officers. The doctrine thus implicates the separation of powers on the state level. Modern separation-of-powers doctrine has two competing strands. ${ }^{117}$ In one, the three branches are sharply separated. According to this strand, a notification requirement would clearly be imposed on state executive officials, and would be subject to the anti-commandeering requirement. In the other strand, however, the lines are blurred, largely for functional reasons. ${ }^{118}$ This strand might support an argument locating the notification requirement somewhere on the edges of the judicial branch because notification is closely bound up with criminal prosecutions heard by the courts. ${ }^{19}$

Once again history might justify some degree of commandeering pursuant to the Treaty Power. According to Professor A. Mark Weisburd, "early treaties included topics that apparently required action by local executive officials. ${ }^{\$ 120}$ One

115. Id. at 126-27. Thornberry notes that of course governors will take the latter course, quoting then-Governor George W. Bush: "In general, I will uphold the laws of the State of Texas, regardless of the nationality of the person involved." Id.

116. I do not mean to claim that the argument is powerful or persuasive in its original context, but only that it is no less powerful or persuasive in the present one.

117. The classic discussion is Peter Strauss, Formal and Functional Approaches to Separation of Powers Questions: A Foolish Inconsistency?, 72 CORNELI L. REV. 488 (1987).

118. See Strauss, supra note 117.

119. Thornberry, supra note 86 , at 142 , suggests that the anticommandeering principle would be avoided in the Breard context by requiring a determination "at every defendant's initial [judicial] hearing" of whether the defendant is a foreign national, and requiring notification of foreign nationals' rights at that time; see also Vázquez, supra note 74, at 1326 n. 30 (making the same suggestion).

120. Weisburd, supra note 30, at 903. Professor Weisburd's prime example is a convention concluded in 1788 (implementing a treaty made in 1778) requiring a party's "officials competent" to arrest deserters from the other nation's merchant ships. As Professor Weisburd points out, one might 
might read the Court's anti-commandeering decisions to mean that commandeering that lacks a decent historical pedigree is impermissible, leaving open the possibility that long-established forms of commandeering, such as consular notification, are constitutionally permissible.

The Court has offered another, substantially more expansive way of working around the anti-commandeering principle. ${ }^{121}$ The analysis is deceptively simple. Assume that Congress may preempt state action, directing the states to do nothing about a particular problem. Then, according to the Court, Congress can restore authority to the states on condition that they enact legislation Congress wants or on condition that their executive officers do something that Congress wants.

Professor Carlos Vázquez defends the Vienna Convention's requirements by invoking the conditional preemption doctrine. ${ }^{122}$ According to him, the Convention says to state officials, "of course you don't have to arrest foreign nationals, but if you do, you have to notify them of their rights under the Convention. ${ }^{\text {1123 }}$ Professor Vázquez's argument is entirely compatible with the Court's articulated doctrine, but it has the effect of trivializing the anti-

mistakenly think that the relevant "officials competent" would be officials of the national government. But there were no such officials in 1788; the Constitution had been completed but the national government was not yet organized. See id. Professor Weisburd acknowledges the possibility that a duty imposed on state officials in 1788 was transferred to federal officials when the national government was organized, but argues that doing so "would have required the establishment of a substantial federal police force in a good many port cities," a requirement that he correctly thinks implausible to attribute to the Framers. Id. at 903 n.142.

121. See James A. Deeken, Note, A New Miranda for Foreign Nationals? The Impact of Federalism on International Treaties that Place Affirmative Obligations on State Governments in the Wake of Printz v. United States, 31 VAND. J. TRANSNAT'L L. 997, 1030 (1998) (arguing that a state's failure to notify foreign nationals of their rights under the Vienna Convention might be said to interfere with the purposes of the Convention). If this is a valid argument, then the Convention would preempt something, but it is not entirely clear what: maybe the state's prosecution or state rules immunizing police officers from monetary liability for unlawful action. Deeken argues that the Convention itself does not establish a rule requiring the exclusion of evidence acquired as a result of a failure to comply with the Convention's notification requirement. Id. at 1036-38.

122. See Vázquez, supra note 74.

123. Id. at 1325. The national government's power to deny state officials authority to arrest or prosecute foreign nationals arises from its power over foreign relations. Other nations might trust the U.S. government but not subnational governments, and might insist in negotiations that only the U.S. government prosecute their nationals, even for ordinary crimes. That possibility is sufficient to establish that the U.S. government has the power to preempt the application of state criminal laws to foreign nationals. 
commandeering rule. As Professor Vázquez points out, the statutes the Court invalidated as commandeering state officials could readily be re-cast-and even merely re-interpreted-as conditionally preempting state law. ${ }^{124} \mathrm{~A}$ broadly construed doctrine authorizing commandeering by means of conditional preemption would make the anti-commandeering principle one truly of form alone.

That said, the power to commandeer through conditional preemption would seem expansive enough to encompass virtually any imaginable international agreement that would effectively require states to comply with international human rights norms. Consider again the death penalty for juvenile offenders. Recall that I have argued that it is nearly impossible to devise a doctrine that would take some subject matter off the table for international negotiation. If that argument is right, there can be no subject-matter limitation barring the national government from regulating ordinary crime. Pursuant to a treaty, then, Congress could enact a statute making every capital crime committed by a juvenile in states with the juvenile death penalty exclusively a federal offense, punishable by something other than death. With the power to preempt, Congress can then exercise the conditional-preemption power and authorize states to prosecute juvenile offenders but only on condition that they not be subject to capital punishment. ${ }^{125}$

Perhaps the intuition behind the anti-commandeering principle can be salvaged by transforming the Court's concern with the diffusion of political responsibility. As Professor Weisburd puts it, the early treaties "do not purport to bring about fundamental changes in state governmental structures."126 As noted above, Congress's self-serving purposes and impulse to aggrandize its power at the expense of the states might be constrained at least a bit in the treaty context. This is because the other nations with whom the treaty-makers deal may have no interest in helping Congress become more powerful. In this context, then, a rule more limited than the anti-commandeering one might be defensible: the treatymakers cannot enter into agreements that would fundamentally

124. See Vázquez, supra note 74, at 1327-28 (suggesting a rewriting of the Brady Act to invoke the power to preempt on condition); see also Janet $R$. Carter, Note, Commandeering Under the Treaty Power, 76 N.Y.U. L. REV. 598, 618 (2001) (arguing that "finding such proposals to be within Congress's powers would open the door to complete circumvention of states' rights").

125. This example is a bit off-key, because barring states from executing juvenile offenders is not precisely a form of affirmative commandeering. A better example may be a requirement that states that prosecute juvenile offenders confine them in prisons for a federally prescribed number of years.

126. See Weisburd, supra note 30, at 918 (emphasis added); see also HENKIN, supra note 87 , at 148 (describing a similar constraint). 
change state governments.

But, once again, we might wonder about the need for such a doctrine in the modern era. The treaty-makers are hardly likely to accede to requests from other nations that would have the effect of wreaking such fundamental changes.

\section{CONCLUSION}

I have argued that the contours of federalism doctrines limiting U.S. national power in the international arena are difficult to define, and in any event address purely hypothetical problems that are unlikely to be real matters of policy-making concern in the new constitutional order. However, were the Court to announce a limiting doctrine, it might change the domestic playing field. It would present proponents of incorporating international human rights norms into U.S. domestic law with another argument, beyond the existing, essentially policy-based ones, that they would have to overcome. To do so, they might well have to make some concessions of their own, leading to the adoption of a treaty in a different form from the one that would have been adopted were it clear that the treaty-makers had plenary power. Resolving the controversy over the existence of federalism limits on the treaty power thus has consequences even in the new constitutional era. The United States is unlikely to adopt the most expansive international human rights proposals currently on the international agenda. It might, however, agree to some modest proposals. Were the treaty-making community (academics, members of Congress, executive branch officials, and judges) to accept the proposition that there are federalism limits on the treaty power, whatever the United States adopts will be even more limited.

We are in the early days of the new constitutional order. I have argued that we can expect few bold initiatives from either the treaty-makers or the courts in this new order. The Supreme Court has articulated doctrines that might be developed in ways that would work large changes in what the past generation assumed the treaty-makers could do. We should expect, though, that the doctrines will not be developed in such ways. Nor should we expect that the need will arise for the courts to invoke doctrines limiting national power in the name of federalism. ${ }^{127}$

127. In one sense this observation echoes Professor Thomas Franck's pessimism about the incorporation of international norms into U.S. law and policy, and offers some structural and political considerations supporting his normative concerns. Thomas M. Franck, Dr. Pangloss Meets the Grinch: $A$ Pessimistic Comment on Harold Kob's Optimism, 35 HOUS. L. REV. 683 (1998). 
HeinOnline -- 47 Wayne L. Rev. 870 2001-2002 